\title{
Speech Act Analysis to Short Stories
}

\author{
Sahar Farouq Altikriti \\ Dept. of English Language, Al Isra University, Amman, Jordan \\ Email: smallcrystals@yahoo.com
}

\begin{abstract}
The study of meaning in context is the core of pragmatics, yet to identify or pinpoint what is a context is difficult. In fact, context of the language of any literary work may be felt in the text but not all the time, since understanding literary works may be dependent on cultural contexts which are not found in the text. Hence the paralinguistic and extra linguistic clues of relating meaning to context has to do with the attempt to get at the intended meaning of an utterance. This is clearly explained by Sadock (1974) and Green (1975) as they claimed that speech act theory which hypothesizes that there should be a one to one relation between surface form and encoded illocutionary force for direct speech acts meets with unsurmountable difficulties. From theoretical and experimental perspectives, there were several studies concerning speech act theory as one of the basic elements for studying pragmatics. Literary texts, novels, and drama have received a quite good pragmatic attention, but not much has been paid to short stories. As such, the present study was carried out with the aim of examining three short stories and analyzes them pragmatically. It has come to the findings that the use of speech acts fluctuate both in quantity and type from one writer to another and from one theme to another.
\end{abstract}

Index Terms - Speech Act Theory, narrative fictionality, 'Acme', 'Post Haste and 'The Happy Prince'

\section{REVIEW OF LITERATURE}

\section{A. Preliminaries to Speech Act Theory}

Sometimes, when we want to teach our children important factors in life such as "Don't play with fire", "Behave well", "Stop yelling", etc., then, we are using statements that reflect a paradigmatic use of language, i.e., we can make requests, ask questions, give orders, make promises, give thanks, offer apologies, and so on. But, to infer what is said (considering its form and context) is an essential ability for the creation and reception of coherent discourse which would lead to a successful communication. Reaching such ability requires the knowledge of the physical and social world and assumptions about the knowledge of the people with whom we are interacting. Formulating this knowledge is the essence of what is called the Speech Act Theory. Speech act theory provides us with a means of digging beneath the surface of discourse and establishing the function of what is said (Cook 1992). In other words, speech act theory attempts to explain how speakers use language to accomplish intended actions and how hearers infer intended meaning form what is said. Although speech act studies are now considered a sub-discipline of cross-cultural pragmatics, they actually take their origin in the philosophy of language:

It was for too long the assumption of philosophers that the business of a 'statement' can only be to 'describe' some state of affairs, or to 'state some fact', which it must do either truly or falsely. (...) But now in recent years, many things, which would once have been accepted without question as 'statements' by both philosophers and grammarians have been scrutinized with new care. (...) It has come to be commonly held that many utterances which look like statements are either not intended at all, or only intended in part, to record or impart straight forward information about the facts (...). (Austin, 1962, p.1)

In 1930s, there was a belief that unless the sentence can be verified, it is meaningless. This was based on the doctrine of "Logical Positivism" where most of the ethical, aesthetic and literary discourses and everyday utterances were simply meaningless. In contrast to this rather limited view, which when actually compared to the full range of utterances in the real world is forced to exclude most of them as simply nonsensical; Austin, particularly his How to Do Things with Words, proposes a second category of utterances that are not subject to the truth/falsity conditions of propositional knowledge. Rather, these exist as acts in themselves that is--as Austin dubs them--as performatives. The peculiarity of the performative utterance, in contrast to the constative, is that it does not describe a state of affairs independent of itself, but that it is itself the reality it describes. It is therefore a self-reflexive utterance. Austin's archetypal examples of these are the acts of naming, marrying, bequeathing and betting. In other words, as Levinson (1983) states:

Performatives are, if one likes, just rather special sorts of ceremony. And unlike constative, which are assessed in terms of truth and falsify, performatives can only be assessed as felicitous or infelicitous, according to whether their felicity conditions are met or not.

Moreover, Van Oort (1997) argues that utterances such as "I name this ship HMS Hermes," does not describe a state of affairs in the real world, rather it brings a state of affairs into existence by virtue of the utterance. The act of naming is simultaneously the reference of this statement and the performative is therefore, in the most rigorous sense, an act and not a representation of something else, at least not in the preferred constative sense of a representation. Thus, Austin (1962) presented a distinction between two types of Performatives: Explicit and Inexplicit. Austin contended that the 
explicit performative utterances are, unlike statements, neither true nor false. For example, a performative promise is not, and does not involve, the statement that one is promising. It is an act of a distinctive sort, the very sort (promising) named by the performative verb, such as , "I promise to do the dishes" in an appropriate context is not only a matter of saying or describing something, rather, in making this utterance the promise is performed. Since promising is an illocutionary act, the utterance is thus a performative utterance. On the other hand, Austin pointed out that the sentence may be uttered without the intention to keep the promise then it is called "infelicitous" according to felicity conditions. However, there are also "implicit", or "inexplicit" performatives; for instance, if someone says "Go", in order to command someone to leave the room then this utterance is part of the performance of a command; and the sentence, according to Austin, is neither true nor false; hence the sentence is a performative; yet, it is not an explicit performative, since it is not clear that the speaker is performing an act of command. In other words, as Verscheuren (1979) (cited in Mey 1993,p.109) states:

We are dealing with a performativity 'continuum' running all the way from institutionalized speech act such as 'to baptize' to everyday verbs that occasionally can take on a performative character.

Moreover, the same utterance could at the same time constitute three kinds of acts:

1- a locutionary act (or locution): The particular sense and reference of an utterance;

2- an illocutionary act (or illocution): The act performed in, or by virtue of, the performance of the illocution; and

3- a perlocutionary act (or perlocution): The act performed by means of what is said.

Austin focused on the second of these acts. The locution belongs to the traditional territory of truth-based semantics. The perlocution belongs strictly beyond the investigation of language and meaning since it deals with the results or effects of an utterance. The illocution occupies the middle ground between them. This ground is now considered the territory of pragmatics, of meaning in context. Austin emphasizes his claim that only the verbs used to describe illocutions can be used as performative verbs ( Bates 1976, Lyons 1977, van Dijk 1977, Levinson1983; Brown \& Yule 1983 Spenader, J. 2004).

In 1969 \& 1979 Searle and many others have developed the basic elements of Austin's speech acts to become what is called Speech Act Theory. Searle has introduced the notion of an 'indirect speech act', which in his account is meant to be, more particularly, an indirect 'illocutionary' act. Applying a conception of such illocutionary acts according to which they are (roughly) acts of saying something with the intention of communicating with an audience, he describes indirect speech acts as follows:

In indirect speech acts the speaker communicates to the hearer more than he actually says by way of relying on their mutually shared background information, both linguistic and nonlinguistic, together with the general powers of rationality and inference on the part of the hearer. (Searle, 1975,p.60)

An account of such act, it follows, will require such things as an analysis of mutually shared background information about the conversation, as well as of rationality and linguistic conventions.

In connection with indirect speech acts, Searle introduces the notions of 'primary' and 'secondary' illocutionary acts. The primary illocutionary act is the indirect one, which is not literally performed. The secondary illocutionary act is the direct one, performed in the literal utterance of the sentence (Searle, 1985). In the example:

(1) Speaker X: "We should leave for the show or else we'll be late."

(2) Speaker Y: "I am not ready yet."

The primary illocutionary act is Y's rejection of X's suggestion, and the secondary illocutionary act is Y's statement that she is not ready to leave. By dividing the illocutionary act into two subparts, Searle is able to explain that we can understand two meanings from the same utterance all the while knowing which the correct meaning to respond to is. Searle, in his doctrine of speech act, attempts to explain how it is possible that a speaker can say something and mean it, but additionally mean something else. This would be impossible, or at least it would be an improbable case, if in such a case the hearer had no chance of figuring out what the speaker means (over and above what she says and means). Searle's solution is that the hearer can figure out what the indirect speech act is meant to be, and he gives several hints as to how this might happen.

Tsohatzidis (1994) agrees with Searle in that the logical theory of success and satisfaction for illocutionary acts can be developed on the basis of few basic principles:

(a) Each illocutionary force can be divided into six types of components which are an illocutionary point, a mode of achievement of that point, preparatory and sincerity conditions and the degree of strength;

(b) The set of illocutionary forces is recursive;

(c) The conditions of success of elementary illocutionary acts are entirely determined by the components of their force and their force and their propositional contents;

(d) The conditions of satisfaction of elementary illocutionary acts are entirely determined by their propositional content and their direction of fit.

Due to these principles, the relation between the propositional content and the world is realized through the performance of a speech act and from which the direction of fit between words and things may be interpreted. Such direction can be clearly realized in terms of four levels, (Searle1979, Leech 1983, Mey1993):

(1) The words - to - world direction of fit: 
Once the illocutionary act is satisfied, its propositional content fits the state of affairs existing in general independently in the world. This expresses a belief, making words fit the words and committing the speaker to the truth of what is asserted, for example: asserting, reporting, instructing, concluding, responding, wishing, etc.

(2) The world - to - words direction of fit (commissives and directives):

When the illocutionary act is satisfied, the world is transformed to fit the propositional content. All speech acts with the commissive and the directive points, such as promises, vows, requests and orders, have the world direction of fit. While commissives express, an intention, making the world fit the words and counting as a commitment for the speaker to engage in a future course of action, for example: offering, inviting, vowing and promising.

(3) The double direction of fit (declarative):

If the illocutionary act is satisfied, the world is transformed by an action of the speaker to fit the propositional content by the fact that the speaker represents it as being so transformed. Thus, such speech acts do not express any psychological state by making both the words and the world fit the words and the point of which to bring a change in (institutional) reality, such as baptizing, declaring war, excommunicating resigning, sentencing, etc.

(4) The empty direction of fit (expressive):

No direction of fit do exists as long as a certain psychological state is expressed and in which a wide range of psychological states can be expressed. Therefore, the proposition ascribes a property or act to the speaker or the hearer, for example: apologizing, thanking, congratulating, greeting, etc.

Searle further distinguished the "illocutionary point" from both "illocutionary act" and "illocutionary force". Hence, he identified the five primitive illocutionary forces which are the simplest possible forces and they are the following:

1- The force of assertion which is named by the performative verb "assert" and realized in the syntactic type of declarative sentences;

2- The primitive commissive illocutionary force which is named by the performative verb "commit";

3- The primitive directive illocutionary force which is realized in the type of imperative sentences;

4- The force of declaration which is expressed in performative utterances;

5- The primitive expressive illocutionary force which is realized in the syntactic type of exclamatory sentences.

Austin's taxonomy of speech acts is not flawless since it involves many faults such as inconsistency and incompleteness. As a result of these faults, Searle focused only on four of the twelve criteria of the classificatory procedure of the speech acts (Illocutionary Point, Direction of Fit, Psychological State, and Content). Thus, two conditions were raised:

\section{1- Reference to Speaker 'S' or Hearer ' $H$ ';}

2- Context Conditions.

On these bases, Searle (1979), as an improvement of the classification of the speech acts proposed by Austin, classifies speech acts into five categories, (Searle 1985, Leech 1983, Leech and Thomas, 1985, Mey 1993, Yule 1996):

1- Representative: these speech acts carry the values 'true; or ' falls', i.e., they commit the speaker to the truth of the expressed proposition such as asserting, reporting, instructing, concluding, etc.

2- Directives: the speaker's role is to get (to direct)the hearer to do something (or towards some goal)

3-Commissives: Seale calls it "unexceptionable", i.e. the obligation created in the word by commissives is created in the speaker not in the hearer. So they commit the speaker to some future action, such as offering, threatening, promising, etc.

4- Expressives: these express an inner state of the speaker. They tend to be intrinsically polite as in greeting, thanking, congratulating, etc.; and the reverse is true as in blaming and accusing.

1- Declarations: these show the correspondence between the prepositional content and reality and as Searle calls "a very special category of speech acts", such as resigning, dismissing, christening, naming, sentencing, etc.

Undoubtedly, it is realized that Searle's classification resembles Austin's, but, in one respect, Searle's taxonomy is superior to Austin's. Hence, Searle has introduced the notion of an 'indirect speech act', which in his account is meant to be, more particularly, an indirect 'illocutionary' act. Applying a conception of such illocutionary acts according to which they are (roughly) acts of saying something with the intention of communicating with an audience, he describes indirect speech acts as follows: "In indirect speech acts the speaker communicates to the hearer more than he actually says by way of relying on their mutually shared background information, both linguistic and nonlinguistic, together with the general powers of rationality and inference on the part of the hearer." (Searle 1975, p.67). An account of such act, it follows, will require such things as an analysis of mutually shared background information about the conversation, as well as of rationality and linguistic conventions. In connection with indirect speech acts, Searle introduces the notions of 'primary' and 'secondary' illocutionary acts. The primary illocutionary act is the indirect one, which is not literally performed. The secondary illocutionary act is the direct one, performed in the literal utterance of the sentence. In the example:

(1) Speaker X: "We should leave for the show or else we'll be late."

(2) Speaker Y: "I am not ready yet."

Here the primary illocutionary act is Y's rejection of X's suggestion, and the secondary illocutionary act is Y's statement that she is not ready to leave. By dividing the illocutionary act into two subparts, Searle is able to explain that we can understand two meanings from the same utterance all the while knowing which the correct meaning to respond 
to. With his doctrine of indirect speech acts Searle attempts to explain how it is possible that a speaker can say something and mean it, but additionally mean something else. This would be impossible, or at least it would be an improbable case, if in such a case the hearer had no chance of figuring out what the speaker means (over and above what she says and means). Searle's solution is that the hearer can figure out what the indirect speech act is meant to be, and he gives several hints as to how this might happen.

\section{B. The Pragmatics of Narrative Fictionality}

From the late 1970s onwards, there ensued attempts to apply speech act theory in the interpretation of literary texts. These first contributions suggest the analytic value of speech act analysis for literary criticism. At the same time, however, these contributions are almost exclusively devoted to drama, owing, of course, to the centrality of dialogue in this genre. Yet the analysis of speech acts also offers new insights into narrative, as this research sets out to show.

Walsh (2007) clearly pointed that fiction is usually understood to have a second-order relation to the real world, via the mimetic logic of fictional representation, i.e., it represents events, or imitates discourses, that we assimilate through nonfictional modes of narrative understanding. Narratives are constructs, and their meanings are internal to the system of narrative. For some theorists, this general quality of narrativity subsumes the concept of fictionality entirely: if all narratives derive their meaning from their relation to other narratives, rather than any direct purchase on reality, then it no longer makes sense to use this second-order kind of relation specifically to characterize fiction. Since the logic of narrative representation has no benefit to the distinction between fiction and nonfiction, then the focus of theoretical attention is more about the act of fictive narration rather than the substance of fictional narrative. This, hence, leads to an important question:" How can a fictive narration be a referential act, or even an act of communication?" To have a clear understanding, there is a need for pragmatic approach that is advocated to the issue of fictionality, (Tranvott, E.C. and Pratt, M. L. 1980).

As text examples, three short narratives were chosen in which the stories' overall meaning resides to a large extent in the particular speech acts by the characters in communication with each other, in the order these individual speech acts are sequenced in each story, and in the way the figural speech acts are contextualized with speech acts on the level of narrative transmission. These stories are:

1- 'Acme' by Colin Galsworthy,

2- 'Post Haste' by Colin Howard,

3- 'The Happy Prince' by Oscar Wild.

In the following sections, a brief review to each story will be presented and followed by the pragmatic analysis for the utterances stated by the characters of the stories. In addition, breakdown of speech acts and their illocutionary forces realized out of the data analysis are displayed in three tables.

\section{Application of Pragmatic Analysis to the Data ('ACME', 'Post Haste AND 'The Happy PRINCE')}

\section{A. The Analysis of 'Acme' by Colin Galsworthy (1867-1933)}

The story is concerned with the notion of perfection, in both friendship and self confidence. Galsworthy has a friend who is also a writer named Bruce and in his 60s. Bruce is an excellent writer once considered by people as genius, but because of his old age and sickness and because of the loss of self-confidence, he deprived himself from people and fame. Galsworthy is an example of a true friend who tried and succeeded afterwards in raising Bruce's self-confidence in him and in his works as well.

\section{Representatives}

Through the analysis of the text "Acme", it is the representative speech act that is highly used with (49) instances and represents $23 \%$ out of the total number of utterances in the whole text (212). Within this speech act there are forces which have different frequencies. In the following example, there are 33 instances of an assertive illocutionary force representing $17 \%$ out of the total (49):

Example (1): You live out of the world - you don't realize what humdrum people want; something to balance the grayness, the - the banality of their lives. They want blood, thrill, and sensation of all sorts. You didn't mean to give it them a benefit, whether you've done them a benefit, whether you've done them a benefit, whether you wish to or not, and the money's yours and you've got to take it.

This is an example of a representative speech act of an assertive illocutionary force realized when Galsworthy signed a contract with cinema to make out of Bruce's story a film. Bruce expresses his intention to break the walls of isolation and let his works be well known to people.

A concluding illocutionary force occurs in the text in 3 instances making 6\% out of the total (49), such as when Galsworthy addresses Bruce in the following example:

Example (2): I know that you hate and despite the film.

On the other hand, the responding illocutionary force is revealed in 13 instances and represents $27 \%$ out of the total (49). Consider one of Bruce's answers to Galsworthy's question:

Example (3): Galsworthy: Who's attending you?

Bruce: Doctors! They take your money, that's all. I've got no money.

2. Directives: 
The presence of this directive speech act in the text is limited to 6 instances of utterances making up 3\% out of the total (212), and most of its types occur with varied frequencies. Consider the following examples:

Example (4): May I have a look at your skit, when you've finished it?

In this example Galsworthy is cautious in his request to see the skit since Bruce considers his own new story is nothing but a skit. Thus, this utterance is a directive speech act of requesting illocutionary force which represents the least in frequency representing 33\% out of the total (6). In another situation, Bruce was completely shocked when he knew that Galsworthy had sold the scenario to the cinema as in:

Example (5): What? Who'd print a thing like that?

This is an example of a directive speech act of a questioning illocutionary force. This type is realized three times making up 50\% out of the total (6), whereas the responding illocutionary force occurs twice representing $33 \%$ out of the total. This latter type can be clearly shown when Galsworthy asked Bruce for the possibility to keep the skit with him for a long time, but the answer was a literal interpretation of Bruce's lack of self confidence that consequently raised the following question:

Example (6): Skit? What Skit?

It is worthy saying that directive speech act has no reference to an ordering illocutionary force in the text.

3. Commissive:

Through data analysis, it is noticed that commissive speech acts has only one reference in the text. This is shown when Bruce expressed his acceptance to give Galsworthy the skit:

Example (7): Take the thing - it's amused me to do it.

Bruce in this statement clearly reflects his lack of confidence to what he has achieved calling the skit as "thing", i.e. unworthy. This speech act is of an offer illocutionary force making up $100 \%$ out of the total.

4. Expressive

The realization of expressive speech act is shown in 8 utterances representing $4 \%$ out of the total (212). Within this speech act, there are five illocutionary forces where only three of them occur in the text:

Example (8): Good God! / Oh! / Ah! / That!

These are examples of surprise illocutionary act occurring in 5 situations with $62.5 \%$ out of the total (8).

Example (9): Hello!

This is a greeting illocutionary force presented in 2 utterances at $25 \%$ out of the total (8).

Example (10): Thanks

It is the only instance of thanking illocutionary force making up $12.5 \%$ out of the total (8).

\section{B. The Analysis of 'Post Haste' by Colin Howard}

The story is about the writer and an absent-minded character, Mr. Simpson. The writer happened to meet Mr. Simpson near post office one night. Mr. Simpson wanted to post a letter, but he noticed that the envelope was not stamped and he had no money to post letter. So he requested the writer to lend him three half pence to get stamps out of automatic stamp machine; but the writer could not find any coins either. However, the writer accompanied Mr. Simpson to his house for having three half pence. After getting the coins and thanking the writer, Mr. Simpson left for post office. As Mr. Simpson dropped the coins in the machine one by one, no stamp came out from it. The stamps were out of stock in the machine. Due to confusion and nervousness, the envelope dropped from his hand into mud. After several frustrating moments to find stamps, the writer suggested him to post the letter unstamped as there was no way left. Once Mr. Simpson posted the letter, he extended his thanks to the writer for his co-operation in posting the letter. At that moment, Mr. Simpson was confused but he did not tell the writer that the letter was simply an invitation to dinner. The next morning, the writer had to pay three pence to the postman for a blue envelope with a large mud blot on it. He, then, came to understand the mysterious behavior shown by Mr. Simpson at the time of parting at night. The letter was, in fact, addressed to the writer.

1. Representative:

Representative acts are of highest frequency in the text under analysis where 27 instances making up $21 \%$ out of the total (127). Consider the following example:

Example (11): The fact is, we're still quite strangers round here, and -well, I'm rather lost to tell you the truth.

In this example, Mr. Simpson is trying to explain and assert that both he and his wife are new in the district, so they need help from others such as Mr. Colin. It is a good example of the representative speech act of an assertive illocutionary force with the frequency of 22 at $81 \%$ out of the total (27). In another situation, while Mr. Colin and Mr. Simpson were busy trying to post the letter, Colin asked Simpson for the necessity to post the letter at that specific night and immediately Simpson confirmed with the following reply:

Example (12): Dear me, Yes! My wife was most insisted about that. She said I wasn't to — it's - well, I don't know it's extraordinarily important, but — but I'd better post it, if you know what I mean.

This is a responding illocutionary force of a representative speech act occurring 4 times making up $15 \%$ out of the total (27). On the other hand, the data analysis revealed that only instance of the wishing illocutionary force exists in the text with $4 \%$ out of the total (27):

Example (13): Perhaps somebody else 
Colin, in this sentence, hopes and wishes to be helped by someone who would lend Mr. Simpson, other than himself, three half pence to get stamps out of automatic stamp machine.

2. Directive:

Directive speech act occupies the second in role among other types in the text under analysis. It is realized in 13 utterances accounting $10 \%$ out of the total (127). The highest frequency goes to the illocutionary force of question as it occurs in 8 instances making up $62 \%$ out of the total (13).Such illocutionary force was clearly shown when Mr. Simpson realized that he had no money while he was heading to the post office to post the letter and, hence, asked Mr. Colin to lend him the cost of the stamp:

Example (14): I wonder if you could lend me three pence.

After wasting a lot of time in looking for stamps, suddenly and finally Colin managed to make Simpson post the letter without the stamps. This was due to the fact that it would be the recipient's problem to pay for the stamps if they were not put by the sender:

Example (15): Now hurry or you'll miss the last collection.

This is an example of a directive speech act with an ordering illocutionary force presented twice in the text at $15 \%$ out of the total (13).

\section{Commissive:}

Three instances of the commissive speech act has been revealed out of data analysis making up $2.3 \%$ out of the total (127). Although three utterances of commissive act occur, yet they have only been represented by the illocutionary force of offer accounting $100 \%$ out of the total (3). Simpson is a complaining person who kept asking Colin for help because he and his wife are new in the neighborhood and consequently he is always in need of help to go anywhere. The following utterance is an example:

Example (16): Here, I'd better come along with you

4. Expressive:

As a result of data analysis, the expressive speech act occurs in 10 utterances making up 8\% out of the total (127). Within this speech act three illocutionary forces (apologizing, thanking and surprise) occurring in 3 instances and accounting $30 \%$ out of the total (10); whereas wishing illocutionary force occurs only once and represents $10 \%$ out of the total (10). The following is an example of many others where Simpson apologizes for the inconvenience that he makes to Colin:

Example (17): Sorry! I - I rather think I've forgotten the way again.

\section{The Analysis of "The Happy Prince" by Oscar Wild}

One night a little swallow flew over the city where a beautiful statue stood. The statue was covered by thin leaves of fine gold; for eyes he had two sapphires and a large red ruby glowed on his sword. When the prince whom the statue was made after was alive he did not know what tears were - he lived in a palace where sorrow was not allowed. The court used to call him the Happy Prince, and when he died the Town Councilors decided to build the statue, which was set up so high that he could see everything in the city. The swallow decided to sleep on the statue's feet, but just when he was putting his head under his wings, he felt a drop of water, and then another. When he looked up he realized that the Happy Prince was crying because he could see the misery and ugliness of his own city. So the Happy Prince asked the swallow to be his messenger and help some of the miserable people by giving them his eyes of sapphire and the ruby from his sword. As a result of this action he became blind and the swallow had to fly over the city in order to tell him what he had seen. At last the swallow realized that he would die because of the cold winter, and he decided to stay with the Happy Prince. The Prince asked the swallow to kiss his lips as he loved him, and once the swallow did so he fell down at the Prince's feet. At that moment a crack sounded inside the statue as the Prince's heart broke. Early the next morning, the Mayor decided to melt it in a furnace. The broken lead heart, however, did not melt, and so it was thrown away on alongside the dead swallow, the Prince's final friend. God decreed that both the swallow and the Prince would live happily in His presence forever.

\section{Representative:}

Through the analysis of the data, the representative speech act carries the high frequency among the other types found in the story of "The Happy Prince". It is presented in 93 utterances making up30\% out of the total (307). The following is an example of the assertive illocutionary forces which occur in 65 instances with 70\% out of the total (93). It is realized when the happy prince tried to do the best for his poor people of his country through his media, i.e. the swallow:

Example (18): Far away, far away in a little street there is a poor house. One of the windows is open, and through it I can see a woman seated at table.

Her face is thin and worn, .................... so he is crying.

The other types of the representative speech act vary in frequency. The next in role come the responding illocutionary force where 19 utterances making up $20 \%$ out of the total (93); whereas both responding and wishing illocutionary forces are of less frequency respectively. The former type occurs in 7 utterances with $8 \%$ and the latter appears only twice with $2 \%$ out of the total (93). Consider the following example:

Example (19): As he is no longer beautiful he is no longer useful. 
It is a concluding illocutionary force expressed by the compilers who decided to remove the golden parts and the jewelry eyes from the statue of the happy prince and give them to the poor people of the kingdom.

2. Directive:

In the case of directive speech act, 23 utterances have been realized with $7.4 \%$ out of the total (307). Requesting as well as question illocutionary forces occur in 9 instances at $39 \%$ out of the total (23):

Example (20): Swallow, Swallow, little Swallow, will not stay with me one night longer?

Example (21): Who are you?

On the other hand, ordering illocutionary force have been realized in 5 utterances making up 22\% out of the total (23), whereas no instances of responding illocutionary force do occur in the text under analysis.

3. Commissive:

Commissive speech act has been realized in 8 instances in the text making up 3\% out of the total (307). The only type of commissive speech act that occurs in the text is that of promising with $100 \%$ out of the total (8). One of these cases is when the swallow promised to stay with the prince in that cold night saying:

Example (22): It is very cold here, but I will stay with you for one night, and be your messenger.

4. Expressive:

As the data under analysis shows, there are 12 utterances of expressive speech act occurring with $4 \%$ out of the total (307). Three illocutionary forces within the expressive speech act vary in their frequencies respectively. Concerning surprise illocutionary force, there are 9 instances with $75 \%$ out of the total (12). The following is an example of the surprise made by the councilors about the shabby look of the prince:

Example (23): Dear me! How shabby the Happy Prince looks!

Apology illocutionary force also occurs in the text with 2 utterances at $17 \%$ out of the total (12), whereas one instance of thanking illocutionary force with $8 \%$ out of the total (12) does occur in the text under analysis. In the following example the prince expresses his thanks to the Swallow for the help the latter did

Example (24): Thank you little Swallow.

It is worth stating that through the data analysis to all three texts; there are no instances of declaration speech act that do occur.

\section{DIRECT AND INDIRECT SPEECH ACTS}

Although most of the utterances in the three stories under analysis are of direct speech act type, yet, there is an instance of indirect speech act in the first and second text, whereas the third text lacks any indirect speech act. Breakdown of direct \& indirect speech acts is clearly displayed in Table (2). In text one, there is one utterance with $0.47 \%$ out of the total (212) where Galsworthy tries to confess to Bruce about what he did with the latter's skit:

Example (25): You remember the skit you wrote, and gave me about six weeks ago?

In this example there is a contrast between the assertive form of the utterance and its function as a question. In the second text under analysis the same perspective is realized in one instance at $0.78 \%$ out of the total (127). This is shown when Colin asks Simpson whether it is necessary to post the letter in that specific night:

Example (26): I suppose it must go tonight?

All the frequencies and percentages mentioned above in the analysis of the three texts are clearly presented in Table One; whereas, those of direct and indirect speech acts are presented in Table Two.

\section{COMPARISONS}

In this part of the study, the three analyzed short stories are compared to show if there is any difference between the types of speech acts with reference to their illocutionary forces. Such comparison is conducted in terms of the process of testing based on the "Z score" formula where X1 and X2 refer to the observed proportions (Dixon and Messy, 1969):

$$
Z=\frac{X 1-X 2}{\sqrt{P(1-P)\left[1 / \mathbf{N}^{1}+\mathbf{1} / \mathbf{N}^{2}\right]}}
$$

$\mathrm{Z}$ score is used to find out whether the differences between proportions constitute any distinctive characteristics and the significance is the tabulated score 1.96 at 0.05 levels. Results of the Three Texts' Analysis are shown in Table Three.

\section{A. The Comparison between the Texts}

\section{Representative:}

In the light of the analysis presented previously in this study, the occurrence of speech acts and their illocutionary forces vary with significance. The following are the frequencies and percentages of each act in the three selected texts:

1- Text one comprises 212 utterances out of which 49 instances are of a representative speech act representing $23 \%$ out of the total;

2- Text two consists of 127 utterances out of 27 instances are of representative speech act making up $21 \%$ out of the total; 
3- Text three has 307 utterances out of which 93 instances are of representative speech act with $30 \%$ out of the total.

The comparison made between each two texts out of the three separately is based on the application of the $\mathrm{Z}$ score mean. The first comparison between "Acme" and "Post Haste" reveals that there is no significance since the computed $\mathrm{Z}$ score, 0.4 , is smaller than the tabulated value, 0.05. On the other hand, there is a significant difference between "Post Haste" and "The Happy Prince" as the calculated result out of the comparison is 33 while the tabulated value is 0.05 . Concerning the illocutionary forces within the representative speech act there are significant differences realized by the $\mathrm{Z}$ score as shown in the following classification:

(a) Assertive:

There is no significant difference between the texts under analysis since the calculated value, 1 , is smaller than the tabulated value.

(b) Concluding:

There is no significant difference between the first and the third text than the tabulated value.

(c) Responding:

The computed values conducted in terms of the $\mathrm{Z}$ score are significant between the first and second text representing 2.5 and that between the first and the third text is 2 since the tabulated value is 0.05 .On the other hand, the comparison between the second and the third text has no significance since the calculated value, 1 , is smaller the tabulated value.

(d) Wishing:

A significant difference is realized between the second and the third text is realized as the calculated value is 2 .

2. Directive:

The directive speech act and its illocutionary forces varied in their frequencies and percentages in the three selected data. The following is a clarification:

1- Text one consists of 212 utterances out of which 6 utterances are directive representing $3 \%$ out of the total;

2- Text two comprises 127 utterances which include 13 utterances making up $10 \%$ out of the total;

3 - Text three has 307 utterances where 23 instances occur with $7 \%$ out of the total.

As a result of the comparison between the first two texts, there is a significant difference since the computed value is 2.8 while the tabulated value is 0.05 . The same is with both first and third text where the calculated value is 2.2 . In contrast, the comparison between the second and the third text shows no significant difference since the computed value 0.9 is smaller than the tabulated value. Within the directive speech act, the illocutionary forces also vary as a result of the comparison between the selected data. The following is an explanation:

(a) Requesting:

In the light of the comparison between the second and the third text, there is significant difference as the calculated value is 2 , while the tabulated value is 0.05 .

(b) Ordering:

No significant difference is realized out of the comparison between the second and the third text due to the fact that the computed value is no more than 1 , and, hence, smaller than the tabulated value.

(c) Questions:

Through the comparison between the first and second text and that between the first and the third one, there is no significant difference the computed value of each pair is smaller than the tabulated value.

(d) Responding Questions:

In the case of responding questions, the comparison revealed one instance of significance between the first and the second text since the computed value is 2 while the tabulated value is 0.05 .

3. Commissives:

The commissive speech act is realized in the following way:

(1)Text one has 212 utterances where only one instance occurs representing $5 \%$ out of the total;

(2) Text two includes 127 utterances where 3 instances occur at $3 \%$ out of the total.

As a result of the $\mathrm{Z}$ score computation, the difference between the first and second text is significant since the calculated value is 2, whereas the comparison between the second and the third text is of no significance as the calculated value 0.18 is smaller than the tabulated value. Similarly is the case with the comparison between the first and the third text. Moreover, there is no significance concerning the illocutionary force of offering as a result of the comparison between the first and second text.

4. Expressive:

The frequencies and percentages in each of the selected texts can be reviewed briefly in the following way:

1- Text one has 212 utterances of an expressive speech act representing $4 \%$ out of the total;

2- Text two consists of 127 utterances out of which 10 instances are presented with $8 \%$ out of the total;

3- Text three includes 307 utterances where 12 instances making up 4\% out of the total.

The result of the $\mathrm{Z}$ score computation shows that there is no significant difference between three texts since they all have a calculated value smaller than the tabulated value 0.05 . In case of the illocutionary forces within the expressive speech act, there are no significant differences between the texts concerning those of apologizing, thanking, and 
greeting. In contrast, there is a significant difference between the second and the third text realized by the illocutionary force of surprise since the computed value is 2 while the tabulated value is 0.05 .

TABLE ONE

BREAKDOWN OF SPEECH ACTS AND THEIR ILLOCUTIONARY FORCES

Text One: 212 Utt.s

\begin{tabular}{|c|c|c|c|c|c|c|c|c|c|c|c|c|c|c|c|c|c|c|c|c|}
\hline$S A$ & \multicolumn{5}{|c|}{ Representative } & \multicolumn{5}{|c|}{ Directive } & \multicolumn{4}{|c|}{ Commissive } & \multicolumn{6}{|c|}{ Expressive } \\
\hline$I F$ & 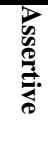 & $\stackrel{\Omega}{\varrho}$ & 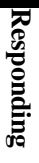 & 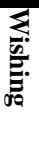 & $\overrightarrow{\mathrm{O}}$ & 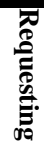 & 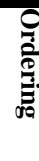 & 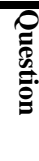 & 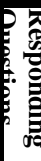 & $\overrightarrow{\overrightarrow{0}}$ & 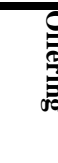 & 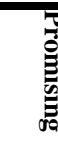 & 㿣 & 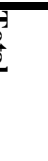 & 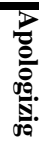 & 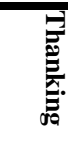 & 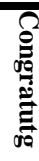 & $\stackrel{\Omega}{\stackrel{8}{8}}$ & 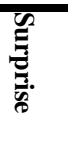 & 2 \\
\hline Fr. & 33 & 3 & 1 & l & 49 & 1 & l & 3 & 2 & 6 & $\mathbf{1}$ & l & I & 1 & I & 1 & I & 2 & 5 & 8 \\
\hline$P c$. & $\begin{array}{l}67 \\
\%\end{array}$ & $\begin{array}{l}6 \\
\%\end{array}$ & $\begin{array}{l}2 \\
7\end{array}$ & $\begin{array}{l}0 \\
\%\end{array}$ & $\begin{array}{l}23 \\
\%\end{array}$ & $\begin{array}{l}17 \\
\%\end{array}$ & $\begin{array}{l}\mathbf{0} \\
\%\end{array}$ & $\begin{array}{l}50 \\
\%\end{array}$ & 33 & $\begin{array}{l}3 \\
\%\end{array}$ & $\begin{array}{l}100 \\
\%\end{array}$ & $\begin{array}{l}0 \\
\%\end{array}$ & $\begin{array}{l}0 \\
\%\end{array}$ & $\begin{array}{l}5 \\
\%\end{array}$ & $\begin{array}{l}0 \\
\%\end{array}$ & $\begin{array}{l}12.5 \\
\%\end{array}$ & $\begin{array}{l}0 \\
\%\end{array}$ & $\begin{array}{l}25 \\
\%\end{array}$ & $\begin{array}{l}62.5 \\
\%\end{array}$ & $\begin{array}{l}4 \\
\%\end{array}$ \\
\hline \multicolumn{21}{|c|}{ Text Two: 127 Utt.s } \\
\hline$F r$. & 22 & I & 4 & 1 & 27 & 2 & 2 & 8 & 1 & 13 & 3 & I & I & 3 & 3 & 3 & I & $\mathbf{1}$ & 1 & 10 \\
\hline Pc. & $\begin{array}{l}81 \\
\%\end{array}$ & $\begin{array}{l}\mathbf{0} \\
\%\end{array}$ & $\begin{array}{l}1 \\
5\end{array}$ & $\begin{array}{l}4 \\
\%\end{array}$ & $\begin{array}{l}21 \\
\%\end{array}$ & $\begin{array}{l}15 \\
\%\end{array}$ & $\begin{array}{l}15 \\
\%\end{array}$ & $\begin{array}{l}62 \\
\%\end{array}$ & $\begin{array}{l}8 \\
\%\end{array}$ & $\begin{array}{l}10 \\
\%\end{array}$ & $\begin{array}{l}100 \\
\%\end{array}$ & $\begin{array}{l}0 \\
\%\end{array}$ & $\begin{array}{l}\mathbf{0} \\
\%\end{array}$ & $\begin{array}{l}2.3 \\
\%\end{array}$ & $\begin{array}{l}30 \\
\%\end{array}$ & $\begin{array}{l}30 \\
\%\end{array}$ & $\begin{array}{l}\text { 0 } \\
\%\end{array}$ & $\begin{array}{l}10 \\
\%\end{array}$ & $\begin{array}{l}30 \\
\%\end{array}$ & $\begin{array}{l}8 \\
\%\end{array}$ \\
\hline \multicolumn{21}{|c|}{ Text Three: 307 Utt.s } \\
\hline $\boldsymbol{F r}$. & 65 & 7 & 1 & 2 & 93 & 9 & 5 & 9 & I & 23 & / & 8 & l & 8 & 2 & 1 & I & I & 9 & 12 \\
\hline$P c$. & $\begin{array}{l}70 \\
\%\end{array}$ & $\begin{array}{l}8 \\
\%\end{array}$ & $\begin{array}{l}2 \\
0\end{array}$ & $\begin{array}{l}2 \\
\%\end{array}$ & $\begin{array}{l}30 \\
\%\end{array}$ & $\begin{array}{l}39 \\
\%\end{array}$ & $\begin{array}{l}22 \\
\%\end{array}$ & $\begin{array}{l}39 \\
\%\end{array}$ & $\begin{array}{l}\text { 0 } \\
\%\end{array}$ & $\begin{array}{l}7.4 \\
\%\end{array}$ & $\begin{array}{l}0 \\
\%\end{array}$ & $\begin{array}{l}100 \\
\%\end{array}$ & $\begin{array}{l}0 \\
\%\end{array}$ & $\begin{array}{l}3 \\
\%\end{array}$ & $\begin{array}{l}17 \\
\%\end{array}$ & $\begin{array}{l}8 \\
\%\end{array}$ & $\begin{array}{l}0 \\
\%\end{array}$ & $\begin{array}{l}0 \\
\%\end{array}$ & $\begin{array}{l}75 \\
\%\end{array}$ & $\begin{array}{l}4 \\
\%\end{array}$ \\
\hline
\end{tabular}

$\mathrm{SA} \rightarrow$ Speech Act / IF. $\rightarrow$ Illocutionary Force / F. $\rightarrow$ Frequency / Pc. $\rightarrow$ Percentage / Utt.s $\rightarrow$ Utterance

TABLE TWO

\begin{tabular}{|c|c|c|c|c|}
\hline & & \multicolumn{2}{|c|}{ BREAKDOWN OF DIRECT \& INDIRECT SPEECH ACT } & \multirow[b]{2}{*}{ Total Utterances } \\
\hline & & Direct Speech Acts & Indirect Speech Acts & \\
\hline \multirow{2}{*}{ Text One } & Fr. & 99 & 1 & \multirow{2}{*}{212} \\
\hline & Pc. & $47 \%$ & $0.47 \%$ & \\
\hline \multirow{2}{*}{ Text Two } & Fr. & 56 & 1 & \multirow{2}{*}{127} \\
\hline & Pc. & $44 \%$ & $\mathbf{0 . 7 8 \%}$ & \\
\hline \multirow{2}{*}{ Text Three } & Fr. & 142 & Zero & \multirow{2}{*}{307} \\
\hline & Pc. & 0.46 & $0 \%$ & \\
\hline
\end{tabular}

\section{B. Direct and Indirect Speech Acts}

Through the computation of $\mathrm{Z}$ score to the direct speech acts, it has been realized that the calculated value of both text one and text two is 0.36 , and that of text two and three is 0.38 ; whereas the value of text one and three is 0.00 , and, hence, they are smaller than the tabulated value. Therefore, the results of $\mathrm{Z}$ score analysis to the selected data are classified in the following way:

1- Through the analysis of the four speech acts, it has been found to be random in the three selected short stories texts and, hence, the mean of significance which should be at the 0.05 level varied among the texts. In other words, the representative speech act is more significant than the expressive whereas the commissive is of the least significance. In this respect, it is the representative speech act that carries the highest significance in the three texts.

2- Concerning the illocutionary forces of each speech act, a clear variation exists as realized in the following points:

(a) Within the representative speech act, the highest significance is realized by the assertion illocutionary force whereas the least goes to that of whishing; 
(b) The illocutionary force of question within the directive speech act carries the highest significance whereas the least is that of a responding question;

(c) For the commissive speech act, the highest significance is realized by the illocutionary force of promising;

(d) Surprise illocutionary force is of the highest frequency whereas that of congratulating has the least significance within the expressive speech act; and

(e) It has been realized that approximately most of the utterances in the short stories are of a direct speech act and this means that they have the highest mean of significance as a result of the $\mathrm{Z}$ score mean.

As a result of the analysis, it has been realized that the use of the speech acts fluctuates in both quantity and type from one writer to another and from one theme to another.

TABLE THREE

RESUlTS OF THE THREE TEXTS’ ANALYSIS

\begin{tabular}{|c|c|c|c|}
\hline Subjects & Results of Z Sc & & \\
\hline SA.S \& IF.S & $\begin{array}{l}\text { Text One } \\
\text { Text Two }\end{array}$ & $\begin{array}{l}\text { Text Two } \\
\text { Text Three }\end{array}$ & $\begin{array}{l}\text { Text One } \\
\text { Text Three }\end{array}$ \\
\hline Representative & 0.4 & 2 & 33 \\
\hline Assertive & 1 & 1 & 1 \\
\hline Concluding & 0.00 & 0.00 & 0.25 \\
\hline Responding & 2.5 & 1 & 2 \\
\hline Wishing & 0.00 & 2 & 0.00 \\
\hline Directive & 2.8 & 0.9 & 2.2 \\
\hline Requesting & 1 & 2 & 1 \\
\hline Ordering & 1 & 0.00 & 0.00 \\
\hline Questions & 0.5 & 1 & 0.2 \\
\hline Responding Questions & 0.00 & 2 & 0.00 \\
\hline Commissive & 2 & 0.18 & 1.86 \\
\hline Offering & 1 & 0.00 & 0.00 \\
\hline Promising & 0.00 & 0.00 & 0.00 \\
\hline Threatening & 0.00 & 0.00 & 0.00 \\
\hline Expressive & 1.64 & 1.7 & 0.11 \\
\hline Appologizing & 0.5 & 0.00 & 0.00 \\
\hline Thanking & 1 & 1.3 & 0.5 \\
\hline Greeting & 0.5 & 0.00 & 0.00 \\
\hline Surprise & 1.5 & 2 & 0.5 \\
\hline Direct SA.s & 0.36 & 0.38 & 0.00 \\
\hline Indirect SA.s & 0.39 & 0.00 & 0.00 \\
\hline
\end{tabular}

\section{CONCLUSION}

In order to become successful communicators, individuals need to understand how different utterance forms can be the vehicles of different communicative intentions. Among the things which a communicator needs to master in order to correctly map an utterance onto its intended interpretation are at least the following: firstly, the linguistic resources required to assign syntactic and semantic structure to the utterance; secondly, an advanced met representational device handling the attribution of mental states; thirdly, a system of social concepts involving status, authority, etc.; finally, a set of higher-order representations specifying how linguistic forms are appropriately used in specific contexts.

It has been concluded that short stories can be analyzed pragmatically similarly to other texts of drama and novel. That the distribution of speech acts is random, there is no significant pattern that embraces the three selected texts. It has also been concluded that the frequency of the illocutionary forces within each speech act is varied from one text to another.

In sum, narrative discourse is amenable to speech act analysis regardless of the different style between novels and short stories.

\section{REFERENCES}


[1] Austin, J. L. (1962). How to do things with words. Oxford: Oxford University Press.

[2] Bates, E. (1976). Language and Context. Academic Press, New York.

[3] Brown,G. \& Yule,G. (1983). Discourse Analysis. Cambridge: Cambridge University Press.

[4] Dixon, J. and Massay (1969). Introduction to Statistical Analysis. New Delhi: Mc Graw - Hill.

[5] Cook,G. (1992). Discourse. Oxford: Oxford University Press.

[6] Eckersely, C.E. (1959). Brighter English: A book of Short Stories, Plays, Poems and Essays. London: Longman.

[7] Green, G. (1975). How to Get People to Do Things with words: The Whimperative Question. In Peter Cole \& Jerry L. Morgan, 1975, pp.107-142.

[8] Leech and Short. (1981). Styles in Fiction: A Linguistic Introduction to English Fictional Prose. London: Longman.

[9] Leech, G (1983). Principles of Pragmatics. London: Longman.

[10] Leech,G. and Thaomas, J. (1985). Pragmatics: The State of the Art. Lancaster. University: Lancaster Papers in Linguistics

[11] Levinson, S. (1983). Pragmatics. Cambridge: Cambridge University Press.

[12] Levinson, S. (2000). Presumptive Meanings: The Theory of Generalized Conversational Implicature. MIT Press.

[13] Lyons, J. (1977). Semantics. Vol.1\& 2. Cambridge: Cambridge University Press.

[14] Mey, J. L. (1993). Pragmatics: An Introduction. London: Blackwell.

[15] Sadock,J(1974).Toward a Linguistic Theory of Speech Acts. New York: Academic Press.

[16] Searle, J.R. (1975). A Taxonomy of Illocutionary Acts. In Günderson, K. (ed.), Language, Mind, and Knowledge, Minneapolis, vol. 7

[17] Searle, J.R. (1979). A Classification of Illocutionary Acts. In Andy Rogers Bob Wall and P. Murphy (ed.s), Proceeding of Texts Conference on Performatives. Prepositions and Implicatures. Washington, Dc: Center for Applied Linguistics.

[18] Searle, John R. and Daniel Vanderveken (1985). Foundations of Illocutionary Logic. Cambridge University Press.

[19] Spenader, J. (2004). Speech Act Theory Introduction to Semantics. http://www.odur.let.rug.nl/spenader/ (accessed 2010).

[20] Traugott,E.C. and Pratt, M. L. (1980). Linguistics for Students of Literature. Santiago: Harcourt Brac Jovanovich Publishers.

[21] Tsohatzidis, S., ed. (1994). Foundations of Speech Act Theory. Routledge, London.

[22] Van Dijk, T. A. 1977. Text and Context: Explorations in the Semantics and Pragmatics of Discourse. London: Longman.

[23] Van Oort, R. (1997). Performative-Constative Revisited: The Genetics of Austin's Theory of Speech Acts. http://www.humnet.ucla.edu/humnet/anthropoetics/Ap0202/Vano.htm. (accessed 2010).

[24] Verscheuren, J. (1979). What People say they do with Words. Unpublished Ph.D. dissertation. In Mey, J. L. (1993). Pragmatics. An Introduction. London: Blackwell.

[25] Walsh,R. (2007). The Rhetoric of Fictionality: Narrative Theory and the Idea of Fiction. Columbus: The Ohio State University Press.

[26] Yule, G. (1996). Pragmatics. Oxford: Oxford University Press.

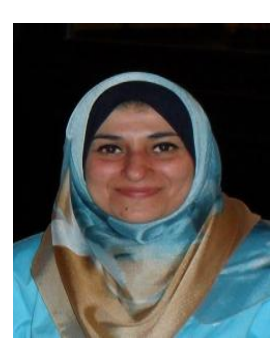

Sahar Farouq Altikriti was born in Baghdad / Iraq 1971. She received her BA and MA in English Language and Linguistics from Al-Mustansiriyah University (1992, 1996), whereas PhD degree in English Language and Linguistics was received from University of Baghdad (2006).

Over the past 17 years she has been teaching English as a foreign language to Arab students in University of Baghdad, Al-Mustansiriyah University (Iraq) and in Al-Isra University and University of Jordan (Jordan). Since then, she has been doing research in the field of linguistics, pragmatics, discourse analysis and applied linguistics.

Dr. Sahar Altikriti is currently an Assistant Prof. of English Language and Linguistics, Al-Isra University / College of Arts / Dept. of English. 